\title{
Nutritional and Biological Value of Five Edible Flower Species
}

\author{
Anna STEFANIAK, Monika GRZESZCZUK* \\ West Pomeranian University of Technology, Szczecin, Department of Horticulture, J. Stowackiego Street 17, 71-434 Szczecin, \\ Poland;Anna.Walejko@zut.edu.pl;Monika.Grzeszczuk@zut.edu.pl (*correspondingauthor)
}

\begin{abstract}
The introduction of edible flowers into our menu and their consumption significantly increases as a result of decorative, taste or aroma qualities. Current research on the chemical composition of edible flowers indicates a high content of vitamins, mineral compounds, essential oils, fibre, mucilage and other compounds characterized by a very high antioxidant activity. The aim of the experiment was to compare the nutritional value and antioxidant activity of three annual and two perennial ornamental plant species with edible flowers: Mimulus x hybridus L. 'Magic Yellow' and 'Magic Red', Antirrbinum majus L. 'Cavalier', Dianthus chinensis L. 'Chianti', Hemerocallis x hybrida Hort. and Monarda didyma L. Among the edible flower species compared in the study, $M$. didyma L. showed the highest nutritional value and antioxidant activity (DPPH and ABTS). While flowers of $D$. chinensis $\mathrm{L}$. 'Chianti' were characterized by highest content of antioxidants such as L-ascorbic acid, total anthocyanins, total polyphenols and ferric reducing antioxidant power (FRAP), $H . \times$ hybrida and $A$. majus $\mathrm{L}$. 'Cavalier' flowers - by the highest content of total soluble sugars and sugar/acid ratio, and M. $\times$ hybridus L. 'Magic Red' and 'Magic Yellow' - by the highest content of total carotenoids.
\end{abstract}

Keywords: Mimulus; Antirrbinum; Dianthus; Hemerocallis; Monarda; chemical composition; antioxidants

\section{Introduction}

Flowers described in the literature as a wonder of nature and a symbol of beauty is an integral part of many people's lives. Moreover, many of the ornamental plant species are edible (Chen and Wei, 2017). For centuries used in culinary art, edible flowers are part of many regional cuisines, including Asian, European and Middle Eastern (Kaisoon $e t$ al., 2012; Fernandes et al., 2017). Flowers can be used as a main ingredient of a dish or as a garnish. They are very popular compounds of such products as liqueurs, vinegars, honeys and oils (Husti et al., 2013; Cunningham, 2015; Petrova et al., 2016). In European countries, the most common use of edible flowers in human nutrition is the preparation of hot beverages. We drink infusions or decoctions, because of their medicinal properties but moreover due to their sensory qualities (Navarro-González et al., 2015; Ngoitaku et al., 2016). Edible flowers have a great impact on color, flavor and appearance of our drinks and dishes (Kelley et al., 2001). In the past, they were mainly consumed for their medicinal properties (Cavaiuolo et al., 2013; Huang et al., 2017). Whereas recently scientists underline also their nutritional value (Cavaiuolo et al., 2013; Lu et al., 2015; Huang et al., 2017). The results of their studies show low caloric value, high content of vitamins, mineral compounds, essential oils, fibre, mucilage and other compounds characterized by a very high antioxidant activity (Rop et al., 2012; Deepika et al., 2014; Navarro-González et al., 2015; Grzeszczuk et al., 2016). As scientists suggest, due to the high content of these active ingredients, edible flowers can potentially be used to prevent chronic diseases (Chen et al., 2015; Dhiman et al., 2017; Pires et al., 2017; Wang et al., 2017). Edible flowers have wide medicinal properties, including: anticancer, antidiabetic, anti-inflammatory, diuretic and antibacterial (Petrova et al., 2016). Flowers of many ornamental plant species are also a rich source of antioxidants capable of removing the negative effects of free radicals (Li et al., 2014; Ngoitaku et al., 2016). In humans, antioxidants play an important role in the prevention of several degenerative and stress-related diseases (Xiong et al., 2014; Dhiman et al., 2017). Antioxidants, such as vitamin C (L-ascorbic acid), carotenoids, anthocyanins and polyphenols, often appear in flowers at higher concentrations compared to common fruit or vegetables (Bor et al., 2006; Mlcek and Rop, 2011; Cavaiuolo et al., 2013).

More and more often we see that edible flowers are a new direction of healthy nutrition (Mlcek and Rop, 2012; Benvenuti et al., 2016). Unfortunately, dishes with fresh flowers are still a challenge for most consumers, including chefs, because the knowledge about their nutritional value is 
still limited (Kelley et al., 2001; Rodrigues et al., 2017). The aim of our study was to assess the content of some nutritional compounds and antioxidant activity of selected species with edible flowers: Mimulus $\times$ bybridus L. 'Magic Yellow' and 'Magic Red', Antirrhinum majus L. 'Cavalier', Dianthus chinensis L. 'Chianti', Hemerocallis $\times$ bybrida Hort. and Monarda didyma L.

\section{Materials and Methods}

\section{Plantmaterial}

The experiment was carried out in the years 2014-2016 at 'The Edible Flower Collection' of the Department of Horticulture of the West Pomeranian University of Technology in Szczecin. The laboratory part of the experiment was conducted in the laboratory of the Department of Horticulture of the West Pomeranian University of Technology in Szczecin. The research material consisted of three annual and two perennial ornamental plant species with edible flowers: Mimulus $\times$ bybridus $\mathrm{L}$. 'Magic Yellow' and 'Magic Red' - yellow and red petals, respectively; Antirrbinum majus L. 'Cavalier' - orange-pink petals; Dianthus chinensis L. 'Chianti' - dark maroon/almost black, white edged petals; Hemerocallis $\times$ bybrida Hort. - orange-yellow petals; Monarda didyma L. bilabiate, carmine red flowers gathered in 1-3 whorls with reddish bracts (Grzeszczuk et al., 2018).

The experimental plot area was: $1.8 \mathrm{~m}^{2}$ for $M$. $\times$ bybridus cultivars $\left(30 \times 30 \mathrm{~cm}, 20\right.$ plants per plot), $5.76 \mathrm{~m}^{2}-$ A. majus $\left(30 \times 30 \mathrm{~cm}, 64\right.$ plants per plot), $4.32 \mathrm{~m}^{2}-D$. chinensis $\left(30 \times 30 \mathrm{~cm}, 48\right.$ plants per plot), $2.4 \mathrm{~m}^{2}-H . \times$ bybrida $(120 \times 100 \mathrm{~cm}, 2$ plants per plot $)$ and $2.16 \mathrm{~m}^{2}$ for $M$. didyma $(60 \times 60 \mathrm{~cm}, 6$ plants per plot). The planting material of $M . \times$ bybridus was bought in an ornamental plant nursery and planted on the experimental plots on the 19th May 2014 and on the 20th May 2015. The seedlings of $A$. majus and $D$. chinensis were produced in the greenhouse. Seeds were sown on the 17th March 2014 and 2015. The seedlings were transplanted into the open field on the 19th May 2014 and on the 21st May 2015. The planting material of $H$. $\times$ bybrida was bought in an ornamental plant nursery and planted on the experimental plots on the 19th May 2014. The seedlings of $M$. didyma were produced in the greenhouse. Seeds were sown on the 22th April 2014. The seedlings were transplanted into the open field on the 18th August 2014. The flowers of $M$. didyma were collected the following two years (2015 and 2016).

The field was prepared according to the proper agrotechnical procedure for the tested species plants (Newerli-Guz, 2016). Mineral fertilization was quantified according to the results of the chemical analysis of the soil. During the field work in all years of the study mineral fertilization, in the form of NPK in amounts: $50: 50: 80 \mathrm{~kg}$ $\mathrm{ha}^{-1}$, was applied. Agrotechnique included mainly irrigation, weeding and soil cultivation.

The flower harvest was done at full-bloom stage $(M . \times$ bybridus - in the middle of June; $A$. majus, D. chinensis, $H$. $\times$ bybrida - at the beginning of July, M. didyma - in the middle of July). An aggregate sample from the four field replications weighed from 50 to $150 \mathrm{~g}$, depending on a plant species.

\section{Laboratory analysis}

The chemical analyses of raw plant material included the determination of the content of dry matter (drying at $105{ }^{\circ} \mathrm{C}$ to constant weight), total ash (incineration of samples in $500{ }^{\circ} \mathrm{C}$ ), crude fibre (Klepacka, 1996) and total protein (using factor 6.25 for the determined total nitrogen amount by the method of Kjeldahl). Moreover, the content of total soluble sugars, reducing sugars and saccharose (by the method of Luff-Schoorl), and titratable acidity (ISO 750,1998 ) were determined. The sugar to acid ratio (total soluble sugars / titratable acidity) was calculated, too. The experiment was also concerned about the content of total chlorophylls, chlorophyll $\mathrm{a}$ and $\mathrm{b}$ (Lichtenthaler and Wellburn, 1983), vitamin C as L-ascorbic acid (by the method of Tillmans), total carotenoids (Lichtenthaler and Wellburn, 1983) and total anthocyanins (Lee et al., 2005; Anuar et al., 2013). All the determinations were carried out in three replicates.

Preparation of plant extracts for total polyphenol content and antioxidant activity determination

The preparation of plant extracts was performed using the method proposed by Wojdyło et al. (2007) with some modifications. The sample of $1 \mathrm{~g}$ homogenised raw plant material was treated with $80 \%$ aqueous methanol $(\mathrm{MeOH})$ to $100 \mathrm{ml}$ volume. The mixtures were placed in an ultrasonic bath at room temperature and sonicated for 30 minutes $(2 \times 15$ minutes $)$ and then left for 24 hours at room temperature. The obtained extracts were filtered through Whatman No. 1 filter paper. The filtrates were centrifuged at $1500 \mathrm{rpm}$ for 10 minutes. All the extractions were carried out in three replicates. The extracts were kept in $4^{\circ} \mathrm{C}$ and used for the analyses within 24 hours.

\section{Determination of total polyphenol content}

Total polyphenol content was analysed spectrophotometrically using the Folin-Ciocalteu colorimetric method as described by Wojdyło et al. (2007). The plant extract $(100 \mu \mathrm{l})$ was mixed with $0.2 \mathrm{ml}$ of the FolinCiocalteu reagent, $2 \mathrm{ml}$ of distilled water and $1 \mathrm{ml}$ of $20 \%$ sodium carbonate. The samples were allowed to stand for 1 hour at room temperature in darkness. Then the absorbance was measured at $760 \mathrm{~nm}$. Gallic acid (GAE) was used to calculate the standard curve, and the results were expressed as GAE milligrams per $g$ of fresh weight (FW).

\section{Determination of DPPH radical scavenging capacity}

The DPPH (2,2-diphenyl-1-picrylhydrazyl) radical scavenging capacity was evaluated according to the procedure of Kumaran and Karunakaran (2007) and Wojdyło et al. (2007). DPPH (0.3 mM) was dissolved in pure ethanol (99.8\%). The plant extract $(0.6 \mathrm{ml})$ was added to $1.8 \mathrm{ml}$ of pure ethanol $(\mathrm{EtOH})$ and $0.6 \mathrm{ml}$ of $\mathrm{DPPH}$ solution. The samples were incubated at room temperature for 10 minutes in the dark. The reduction of the DPPH radical was determined spectrophotometrically by measuring the absorption at $517 \mathrm{~nm}$. Trolox (TE, 6- 
130

hydroxy-2,5,7,8-tetramethylchromane-2-carboxylic acid) was used for calibrating the standard curve and the results were expressed as $\mathrm{mg}$ of trolox equivalent antioxidant capacity per $\mathrm{g}$ of fresh weight sample ( $\left.\mathrm{mg} \mathrm{TE}^{-1} \mathrm{FW}\right)$.

\section{Determ
(FRAP)}

Determination of ferric reducing antioxidant power

The total antioxidant potential of the samples was determined using the ferric reducing ability of plasma FRAP assay by Wojdyło et al. (2007) as a measure of antioxidant power. The FRAP reagent was prepared by mixing an acetate buffer $(300 \mathrm{mM}, \mathrm{pH} 3.6)$, a solution of $10 \mathrm{mM}$ TPTZ (2,4,6-tris(2-pyridyl)-s-triazine) in $40 \mathrm{mM} \mathrm{HCl}$, and $20 \mathrm{mM} \mathrm{FeCl} 3 \cdot 6 \mathrm{H}_{2} \mathrm{O}$ (iron(III) chloride hexahydrate) at 10:1:1 (v/v/v), and warmed at $37^{\circ} \mathrm{C}$ before using. For the spectrophotometric assay, $2.7 \mathrm{ml}$ of the reagent and $0.3 \mathrm{~m}$ of the sample solution were mixed. The absorbance was taken at $593 \mathrm{~nm}$ after 4 minutes. The standard curve was prepared using different concentrations of trolox. The results were expressed in $\mathrm{mg} \mathrm{TE}$ per $\mathrm{g} \mathrm{FW}$.

Determination of free radical-scavenging ability by the use of a stable ABTS radical cation

The free radical-scavenging activity was determined by the ABTS radical cation decolourisation procedures described by Re et al. (1999), Chew et al. (2007) and Wojdyło et al. (2007) with some modifications. ABTS (2,2'-azino-bis(3-ethylbenzothiazoline-6-sulfonic acid) diammonium salt was dissolved in distilled water to a $7 \mathrm{mM}$ concentration. The ABTS radical cation $\left(\mathrm{ABTS}^{\circ+}\right)$ was produced by reacting the ABTS stock solution with 2.45 $\mathrm{mM}$ potassium peroxodisulfate and kept in darkness at room temperature for $16 \mathrm{hrs}$ before use. The ABTS ${ }^{\circ+}$ solution was diluted with PBS (phosphate buffered saline, $\mathrm{pH} 7.4)$ until its absorbance was equilibrated to $0.7( \pm 0.02)$ at $734 \mathrm{~nm}$ before usage. After the addition of $3.0 \mathrm{ml}$ of the diluted $\mathrm{ABTS}^{\circ+}$ solution $\left(\mathrm{A}_{734}=0.7 \pm 0.02\right)$ to $300 \mu \mathrm{l}$ of methanolic plant extracts, the absorbance reading was taken, exactly 6 minutes after initial mixing. Trolox was used for calibrating the standard curve and the results were expressed as $\mathrm{mg} \mathrm{TE}$ per $\mathrm{g} \mathrm{FW}$.

\section{Statistical analysis}

The results of the study were subjected to an analysis of variance which was performed with AWAR software, made by the Department of Agrometeorology and Applied Informatics, Institute of Soil Science and Plant Cultivation in Pulawy, Poland (Filipiak and Wilkos, 1995). The means were separated by the Tukey's test at $\mathrm{p}=0.05$.

\section{Results and Discussion}

The results of the experiment were given in Tab. 1-5 and presented as means from the years 2015-2016 for Monarda didyma L. and from the years 2014-2015 - for the other species.

The data given in Table 1 shows that among the tested species a significantly higher content of dry matter was noted for the flowers of Monarda didyma L. (18.85\%), Dianthus chinensis L 'Chianti' (18.05\%), and Antirrbinum majus L. 'Cavalier' (13.82\%), while significantly lower - for Hemerocallis $\times$ bybrida Hort. (9.97\%) and Mimulus $\times$ bybridus L. flowers ('Magic Yellow' - 6.68\%, 'Magic Red' $7.40 \%)$. The dry matter content assessed by Rop et al. (2012) for some edible flower species was lower in comparison with our results. For Antirrbinum majus flowers they determined $12.61 \%$ of dry matter, and for Dianthus caryophyllus flowers $-11.55 \%$. However, there are edible flowers which are characterized by higher dry matter content than those tested in our experiment. Seroczyńska $e t$ al. (2006) for edible flowers of winter squash recorded 65.2$78.1 \%$ of dry matter, Grzeszczuk et al. (2016) for lavender $34.01 \%$ and garden verbena $-32.24 \%$. In another study Grzeszczuk et al. (2011) determined $20.01 \%$ of dry matter in chive flowers.

On the basis of the obtained results it was found that Monarda didyma L. flowers were characterized by the highest content of total ash (1.564\% FW), crude fibre $(1.927 \% \mathrm{FW})$ and total protein $(7.817 \% \mathrm{FW})$. In the study of Grzeszczuk et al. (2016) on other species of edible flowers it was shown that they contained from 0.92 (Oenothera biennis L.) to $5.25 \% \mathrm{FW}$ (Viola tricolor L.) of total ash, from 0.18 (Bellis perennis L.) to $5.96 \% \mathrm{FW}$ (Lavandula angustifolia Mill.) of crude fibre and from 0.88 (Begonia semperflorens Link et Otto) to $9.51 \% \mathrm{FW}$ (Salvia splendens Sellow ex Roem. et Shult.) of total protein. NavarroGonzález et al. (2015) recorded in the flowers of Tropaeolum majus, Tagetes erecta and Spilanthes oleracea from 0.63 to $1.44 \% \mathrm{FW}$ of ash and from 1.32 to $2.83 \% \mathrm{FW}$ of protein.

Flavor of edible flowers is related to the content of sugars and acids (Kaack et al., 2005). The content of total soluble sugars, reducing sugars, saccharose, titratable acidity and sugar/acid ratio differed significantly according to the species and cultivar of the tested ornamental plant (Table 2).

Table 1. Content of dry matter, total ash, crude fibre and total protein $(\% \mathrm{FW})$ in selected edible flower species

\begin{tabular}{ccccc}
\hline Species and cultivar name & Dry matter & Total ash & Crude fibre & Total protein \\
\hline Mimulus $\times$ hybridus L. 'Magic Yellow' & $6.68 \pm 0.42 \mathrm{c}$ & $0.533 \pm 0.08 \mathrm{c}$ & $0.635 \pm 0.09 \mathrm{~d}$ & $1.727 \pm 0.65 \mathrm{e}$ \\
Mimulus $\times$ hybridus L. 'Magic Red' & $7.40 \pm 0.34 \mathrm{c}$ & $0.671 \pm 0.09 \mathrm{c}$ & $0.722 \pm 0.01 \mathrm{~cd}$ & $1.865 \pm 0.41 \mathrm{e}$ \\
Hemerocallis $\times$ hybrida Hort. & $9.97 \pm 0.04 \mathrm{bc}$ & $0.503 \pm 0.00 \mathrm{c}$ & $0.491 \pm 0.13 \mathrm{~d}$ & $3.346 \pm 0.38 \mathrm{c}$ \\
Antirrbinum majus L. 'Cavalier' & $13.82 \pm 0.01 \mathrm{ab}$ & $0.637 \pm 0.00 \mathrm{c}$ & $0.961 \pm 0.02 \mathrm{c}$ & $2.692 \pm 0.88 \mathrm{~d}$ \\
Dianthus chinensis L. 'Chianti' & $18.05 \pm 0.62 \mathrm{a}$ & $1.125 \pm 0.30 \mathrm{~b}$ & $1.468 \pm 0.13 \mathrm{~b}$ & $5.610 \pm 0.84 \mathrm{~b}$ \\
Monarda didyma L. & $18.85 \pm 0.18 \mathrm{a}$ & $1.564 \pm 0.12 \mathrm{a}$ & $1.927 \pm 0.19 \mathrm{a}$ & $7.817 \pm 0.68 \mathrm{a}$ \\
LSD $D_{\alpha=0.05}$ & 4.351 & 0.262 & 0.323 & 0.273 \\
\hline
\end{tabular}


Table 2. Content of total soluble sugars, reducing sugars, saccharose and titratable acidity in selected edible flower species

\begin{tabular}{|c|c|c|c|c|c|}
\hline Species and cultivar name & $\begin{array}{c}\text { Total soluble } \\
\text { sugars } \\
(\% \mathrm{FW})\end{array}$ & $\begin{array}{l}\text { Reducing sugars } \\
\qquad(\% \mathrm{FW})\end{array}$ & $\begin{array}{c}\text { Saccharose }(\% \\
\text { FW) }\end{array}$ & $\begin{array}{c}\text { Titratable acidity (\% citric } \\
\text { acid } \\
\text { FW) }\end{array}$ & $\begin{array}{l}\text { Sugar/ } \\
\text { acid ratio }\end{array}$ \\
\hline $\begin{array}{c}\text { Mimulus } \times \text { bybridus L. 'Magic } \\
\text { Yellow' }\end{array}$ & $1.48 \pm 0.00 \mathrm{e}$ & $1.55 \pm 0.08 \mathrm{c}$ & $0.29 \pm 0.19 b$ & $0.27 \pm 0.00 \mathrm{c}$ & $6.32 \pm 0.77 \mathrm{c}$ \\
\hline Mimulus $\times$ bybridus L. 'Magic Red' & $2.25 \pm 0.25 \mathrm{~d}$ & $1.87 \pm 0.62 \mathrm{c}$ & $0.25 \pm 0.15 b$ & $0.32 \pm 0.00 \mathrm{bc}$ & $6.29 \pm 0.40 \mathrm{c}$ \\
\hline Hemerocallis $\times$ bybrida Hort. & $5.60 \pm 0.00 \mathrm{a}$ & $4.92 \pm 0.22 \mathrm{a}$ & $0.27 \pm 0.17 b$ & $0.31 \pm 0.11 \mathrm{bc}$ & $18.08 \pm 1.72 \mathrm{a}$ \\
\hline Antirrhinum majus L. 'Cavalier' & $5.55 \pm 0.37 \mathrm{a}$ & $4.00 \pm 0.20 \mathrm{~b}$ & $1.07 \pm 0.22 \mathrm{a}$ & $0.29 \pm 0.05 \mathrm{c}$ & $17.99 \pm 0.83 \mathrm{a}$ \\
\hline Dianthus chinensis L. 'Chianti' & $4.56 \pm 0.34 b$ & $4.70 \pm 0.25 \mathrm{a}$ & $0.09 \pm 0.01 \mathrm{~b}$ & $0.35 \pm 0.12 \mathrm{~b}$ & $16.08 \pm 0.41 b$ \\
\hline Monarda didyma L. & $2.84 \pm 0.00 \mathrm{c}$ & $1.75 \mathrm{c} \pm 0.29$ & $0.64 \pm 0.14 \mathrm{ab}$ & $0.71 \pm 0.29 \mathrm{a}$ & $3.79 \pm 0.23 \mathrm{~d}$ \\
\hline$L S D_{\alpha=0.05}$ & 0.529 & 0.605 & 0.606 & 0.053 & 1.787 \\
\hline
\end{tabular}

The highest content of total soluble sugars and sugar/acid ratio were found in the flowers of Hemerocallis $\times$ bybrida Hort. (respectively: 5.60\% FW, 18.08) and Antirrhinum majus L. 'Cavalier' (5.55\% FW, 17.99) while the least content of total soluble sugars was noted for Mimulus $\times$ bybridus L. 'Magic Yellow' flowers (1.48\% FW) and the least sugar/acid ratio - for Monarda didyma L. flowers (3.79). The highest content of reducing sugars was noted for Hemerocallis $\times$ bybrida Hort. $(4.92 \%$ FW) and Dianthus chinensis L. 'Chianti' flowers ( $4.70 \%$ FW). Moreover, the flowers Antirrhinum majus L. 'Cavalier' and Monarda didyma L. were characterized by a significantly higher content of saccharose (respectively: 1.07 and 0.64\% FW). When comparing the titratable acidity, it was shown that its highest value was found in flowers of Monarda didyma L. (0.71\% citric acid FW). Grzeszczuk et al. (2016) the highest content of sugars (total soluble, reducing and saccharose) determined in the flowers of lavender (respectively: $3.70,3.11,0.561 \% \mathrm{FW})$, heartsease (3.24, $2.55,0.656 \% \mathrm{FW})$ and borage $(3.08,2.53,0.523 \% \mathrm{FW})$ while the least was noted for wax begonia flowers $(0.21$, $0.19,0.019 \% \mathrm{FW})$. The highest titratable acidity was recorded for wax begonia, heartsease and lavender (respectively: $0.814,0.548,0.398 \%$ citric acid FW) while the least for scarlet sage and borage $(0.190,0.107 \%$ citric acid FW). The flavor of the edible flowers compared in our study was described in the literature as: bitter-salty Mimulus; sweetish/flowerish - Hemerocallis; bitter Anthirrhinum majus; spicy-sweet/slightly bitter - Dianthus; citrus/minty - Monarda (Mlcek and Rop, 2011; Ghosh, 2013; Husti et al., 2013; Deepika et al., 2014; Stefaniak and Grzeszczuk, 2015; Benvenuti et al., 2016). It is in agreement with the results of our study, where flowers of Hemerocallis $\mathrm{x}$ hybrida Hort. and Dianthus chinensis L. 'Chianti' were characterized by a very high sugar content and sugar/acid ratio while the flowers of Monarda didyma L. - by the highest titratable acidity.

The highest content of total chlorophylls was noted in flowers from Monarda didyma L. (461.67 $\left.\mu \mathrm{g} \mathrm{g}^{-1} \mathrm{FW}\right)$ and Dianthus chinensis L. 'Chianti' (369.78 $\mathrm{gg} \mathrm{g}^{-1}$ FW) (Table 3). Moreover, Monarda didyma L. flowers were characterized by the highest content of chlorophyll a (312.74 $\left.\mathrm{ug} \mathrm{g}^{-1} \mathrm{FW}\right)$, while flowers of Dianthus chinensis L. 'Chianti' - by the highest content of chlorophyll b (257.09 $\mu \mathrm{g} \mathrm{g}^{-1} \mathrm{FW}$ ). Petrova et al. (2016) examined five edible flower species. Among the $95 \%$ ethanol flower extracts, the one made of Geranium macrorrhizum L. flowers was found as the richest source of total chlorophylls $-41.5 \mu \mathrm{g} \mathrm{g}^{-1} \mathrm{FW}$.

Vitamin C, carotenoids and polyphenols are considered as the most important antioxidants (Li et al., 2014; Zhang et al., 2015). The main polyphenol compounds determined in edible flowers are: phenolic acid derivatives (chlorogenic, caffeic and p-coumaric acids) and flavonoids (e.g. kaempferol, quercetin, apigenin, naringenin, hesperetin, luteolin) (Skrajda, 2017; Chen et al., 2018; Pires et al., 2018). One of the largest flavonoid group responsible for the red, purple and blue colors of fruits, vegetables and flowers are anthocyanins (cyanidin, delphinidin, pelargonidin, peonidin, malvidin and petunidin) (Martín $e t$ al., 2017). In the presented study flowers of Dianthus chinensis L. 'Chianti' were characterized by the highest content of L-ascorbic acid $\left(89.78 \mathrm{mg}^{\left.100 \mathrm{~g}^{-1} \mathrm{FW}\right) \text { and total }}\right.$ anthocyanins ( $443.47 \mathrm{mg} \mathrm{C} 3 \mathrm{G} 100 \mathrm{~g}^{-1} \mathrm{FW}$ ), while the flowers of Mimulus $\mathrm{x}$ hybridus L. cultivars - by the highest content of total carotenoids ('Magic Red' - 529.68 and 'Magic Yellow' - $473.42 \mu \mathrm{g} \mathrm{g}^{-1}$ FW. Higher content of Lascorbic acid was determined by Grzeszczuk et al. (2016) in the flowers of Tagetes tenuifolia Cav. - $241.20 \mathrm{mg} 100 \mathrm{~g}^{-1}$ FW. Garzón and Wrolstad (2009) determined $71.5 \mathrm{mg} 100$ $\mathrm{g}^{-1} \mathrm{FW}$. for Tropaeolum majus flowers. In the literature we can find data of total carotenoids content of some edible flower species. Seroczyńska et al. (2006) recorded 1.23$18.79 \mathrm{mg}$ of carotenoids per $100 \mathrm{~g} \mathrm{FW}$ for winter squash flowers, Petrova et al. (2016) - $57.2 \mu \mathrm{g} \mathrm{g}{ }^{-1} \mathrm{FW}$ for Calendula officinalis L. and Loizzo et al. (2016) - $3.4 \mathrm{mg} \mathrm{g}^{-1}$ FW for Capparis spinosa. The content of anthocyanins of Antirrbinum majus L. which we assessed was higher in comparison with the results obtained by Benvenuti et al. (2016). They determined for Antirrhinum majus L. with flowers of red color -7.37 , rose -9.73 and white $-0.70 \mathrm{mg}$ C3G $100 \mathrm{~g}^{-1} \mathrm{FW}$.

The highest content of total polyphenols was noted for Dianthus chinensis L. 'Chianti' flowers (12.26 mg GAE g ${ }^{-1}$ FW) and it was higher than determined by Chen et al. (2018) for Dianthus caryophyllus (Table 5). D. chinensis L. 'Chianti' flowers were also characterized by the highest antioxidant activity assessed in the FRAP test (14.22 mg TE $\left.\mathrm{g}^{-1} \mathrm{FW}\right)$. The highest antioxidant activity in the DPPH and ABTS test was determined for Monarda didyma L. flowers (respectively: 7.44 and $18.39 \mathrm{mg} \mathrm{TE} \mathrm{g}^{-1} \mathrm{FW}$ ). 
132

Table 3. Content of chlorophylls ( $\left.\mu \mathrm{g} \mathrm{g}^{-1} \mathrm{FW}\right)$ in selected edible flower species

\begin{tabular}{|c|c|c|c|}
\hline Species and cultivar name & Total chlorophylls & Chlorophyll a & Chlorophyll b \\
\hline Mimulus $\times$ hybridus L. 'Magic Yellow' & $29.08 \pm 0.45 c$ & $11.86 \pm 0.40 \mathrm{c}$ & $13.55 \pm 0.04 \mathrm{c}$ \\
\hline Mimulus $\times$ hybridus L. 'Magic Red' & $34.32 \pm 1.71 \mathrm{c}$ & $14.66 \pm 0.79 \mathrm{c}$ & $16.44 \pm 0.80 \mathrm{c}$ \\
\hline Hemerocallis $\times$ bybrida Hort. & $215.19 \pm 4.05 b$ & $43.98 \pm 2.06 \mathrm{bc}$ & $154.32 \pm 3.22 \mathrm{~b}$ \\
\hline Antirrbinum majus L. 'Cavalier' & $79.99 \pm 2.04 \mathrm{c}$ & $35.29 \pm 2.49 \mathrm{bc}$ & $33.88 \pm 2.14 \mathrm{c}$ \\
\hline Dianthus chinensis L. 'Chianti' & $369.78 \pm 14.68$ a & $86.17 \pm 6.97 b$ & $257.09 \pm 5.98$ a \\
\hline Monarda didyma $\mathrm{L}$. & $461.67 \pm 18.56 \mathrm{a}$ & $312.74 \pm 9.33 \mathrm{a}$ & $107.17 \pm 2.54 \mathrm{~b}$ \\
\hline$L S D_{\alpha=0.05}$ & 125.100 & 68.099 & 58.834 \\
\hline
\end{tabular}

Table 4. Content of L-ascorbic acid, total carotenoids and total anthocyanins in selected edible flower species

\begin{tabular}{|c|c|c|c|}
\hline Species and cultivar name & $\begin{array}{l}\text { L-ascorbic acid } \\
\left(\mathrm{mg} \mathrm{100g}^{-1} \mathrm{FW}\right)\end{array}$ & $\begin{array}{c}\text { Total carotenoids } \\
\left(\mu \mathrm{g} \mathrm{g}^{-1} \mathrm{FW}\right)\end{array}$ & $\begin{array}{c}\text { Total anthocyanins } \\
\left(\mathrm{mg} \mathrm{C} 3 \mathrm{G} 100 \mathrm{~g}^{-1} \mathrm{FW}\right)\end{array}$ \\
\hline Mimulus $\times$ bybridus L. 'Magic Yellow' & $48.41 \pm 3.08 \mathrm{c}$ & $473.42 \pm 17.31 \mathrm{a}$ & $15.71 \pm 0.09 \mathrm{~cd}$ \\
\hline Mimulus $\times$ bybridus L. 'Magic Red' & $41.40 \pm 2.55 \mathrm{~d}$ & $529.68 \pm 22.67 \mathrm{a}$ & $30.33 \pm 0.11 \mathrm{c}$ \\
\hline Hemerocallis $\times$ hybrida Hort. & $75.98 \pm 2.03 \mathrm{~b}$ & $227.11 \pm 6.98 \mathrm{bc}$ & $2.77 \pm 0.03 \mathrm{~d}$ \\
\hline Antirrhinum majus L. 'Cavalier' & $39.79 \pm 0.86 \mathrm{~d}$ & $64.03 \pm 4.64 \mathrm{~d}$ & $12.17 \pm 0.03 \mathrm{~cd}$ \\
\hline Dianthus chinensis L. 'Chianti' & $89.78 \pm 0.08$ a & $261.59 \pm 5.42 \mathrm{~b}$ & $443.47 \pm 0.97 \mathrm{a}$ \\
\hline Monarda didyma $\mathrm{L}$. & $33.38 \pm 3.63 \mathrm{e}$ & $167.20 \pm 4.42 \mathrm{c}$ & $204.42 \pm 0.81 \mathrm{~b}$ \\
\hline$L S D_{\alpha}=0.05$ & 6.737 & 90.944 & 24.835 \\
\hline
\end{tabular}

Table 5. Antioxidant activity of selected edible flower species

\begin{tabular}{|c|c|c|c|c|}
\hline \multirow{2}{*}{ Species and cultivar name } & \multirow{2}{*}{$\begin{array}{l}\text { Total polyphenols } \\
\left(\mathrm{mg} \mathrm{GAE} \mathrm{g}^{-1} \mathrm{FW}\right)\end{array}$} & \multicolumn{3}{|c|}{ Antioxidant activity $\left(\mathrm{mg} \mathrm{TE} \mathrm{g}^{-1} \mathrm{FW}\right)$} \\
\hline & & DPPH & ABTS & FRAP \\
\hline $\begin{array}{c}\text { Mimulus } \times \text { hybridus L. 'Magic } \\
\text { Yellow' }\end{array}$ & $2.21 \pm 0.18 \mathrm{~d}$ & $2.24 \pm 0.43 \mathrm{c}$ & $7.49 \pm 0.60 \mathrm{f}$ & $2.59 \pm 0.16 \mathrm{e}$ \\
\hline Mimulus $\times$ bybridus L. 'Magic Red' & $4.33 \pm 0.19 \mathrm{c}$ & $3.24 \pm 0.38 \mathrm{~b}$ & $11.08 \pm 0.82 \mathrm{c}$ & $6.28 \pm 0.15 \mathrm{c}$ \\
\hline Hemerocallis $\times$ hybrida Hort. & $2.06 \pm 0.02 \mathrm{~d}$ & $3.19 \pm 0.45 b$ & $9.49 \pm 0.69 \mathrm{e}$ & $4.93 \pm 0.17 \mathrm{~d}$ \\
\hline Antirrhinum majus L. 'Cavalier' & $2.66 \pm 0.02 \mathrm{~d}$ & $1.68 \pm 0.23 \mathrm{~d}$ & $9.98 \pm 0.28 \mathrm{~d}$ & $2.54 \pm 0.24 \mathrm{e}$ \\
\hline Dianthus chinensis L. 'Chianti' & $12.26 \pm 1.17 \mathrm{a}$ & $3.18 \pm 0.52 \mathrm{~b}$ & $15.01 \pm 1.75 b$ & $14.22 \pm 0.19 \mathrm{a}$ \\
\hline Monarda didyma L. & $10.57 \pm 0.88 \mathrm{~b}$ & $7.44 \pm 0.53 \mathrm{a}$ & $18.39 \pm 2.61 \mathrm{a}$ & $8.14 \pm 0.07 \mathrm{~b}$ \\
\hline$L S D_{\alpha=0.05}$ & 0.876 & 0.381 & 0.348 & 0.650 \\
\hline
\end{tabular}

Rop et al. (2012) determined total phenolic content for Antirrbinum majus L. flowers and it was similar to our result for this species $-3.49 \mathrm{~g} \mathrm{GA} \mathrm{kg}^{-1} \mathrm{FW}$. Li et al. (2014) compared in their study 51 species of edible flowers. The highest amounts of total phenolic were noted for: Rosa

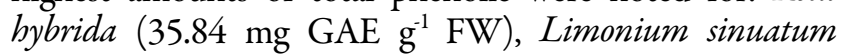
(34.17 mg GAE g $\left.{ }^{-1} \mathrm{FW}\right)$, Jatropha integerrima $(17.22 \mathrm{mg}$ GAE g $\left.{ }^{-1} \mathrm{FW}\right)$, Pelargonium hortorum (25.68 $\mathrm{mg} \mathrm{GAE} \mathrm{g}^{-1}$ $\mathrm{FW}$ ) and Osmanthus. fragrans (16.00 $\left.\mathrm{mg} \mathrm{GAE} \mathrm{g}^{-1} \mathrm{FW}\right)$. A high polyphenol concentration was also noted by Kucekova et al. (2011) and Moravćíková et al. (2012) in Allium schoenoprasum, Rumex acetosa, Tragopogon pratensis and Trifolium repens flowers. Petrova et al. (2016) examined the antioxidant activity of five edible flowers, where one of the extracting agent was $80 \%$ methanol. The highest total phenolic content and antioxidant activity evaluated in the FRAP test were obtained for the flowers of Helianthus tuberosus L. (respectively: $15.20 \mathrm{mg} \mathrm{GAE} \mathrm{g}^{-1} \mathrm{FW}, 107.5 \mathrm{mM}$ TE $\mathrm{g}^{-1} \mathrm{FW}$ ) and in DPPH test - Geranium macrorrbizum L. (156.8 $\left.\mathrm{mM} \mathrm{TE} \mathrm{g}^{-1} \mathrm{FW}\right)$. Chen et al. (2018) were studied 30 flower species and among them the highest total polyphenol content and antioxidant activity was determined in the flowers of Rosa rugosa Thunb., what shows us again that edible flowers are very good sources of bioactive compounds which may be used in food and pharmaceutical industries.

\section{Conclusions}

Monarda didyma L. flowers were found to have the highest nutritional value in comparison with the other edible flower species. They contained one of the highest amounts of dry matter, total chlorophylls, and the highest content of total ash, crude fibre, total protein, chlorophyll a, and moreover they were characterized by the highest titratable acidity and antioxidant activity in the DPPH and ABTS tests. Flowers of Dianthus chinensis L. 'Chianti' had the highest content of L-ascorbic acid, total anthocyanins and total polyphenols; therefore, they can be used for the coloring of sugar, syrups and various potions. Moreover, they contained high amounts of dry matter, reducing sugars, total chlorophylls and chlorophyll $\mathrm{b}$. The highest total soluble sugars content and sugar/acid ratio, important characteristics from the consumer point of view, were noted for Hemerocallis $\times$ bybrida Hort. and Antirrbinum majus L. 
'Cavalier' flowers. Flowers of Mimulus $\times$ hybridus $\mathrm{L}$. cultivars were found to be the best source of total carotenoids in comparison with the other edible flower species.

\section{References}

Anuar N, Adnan AFM, Saat N, Aziz N, Taha RM (2013). Optimization of extraction parameters by using response surface methodology, purification, and identification of anthocyanin pigments in Melastoma malabathricum fruit. The Scientific World Journal http://dx.doi.org/10.1155/2013/810547.

Benvenuti S, Bortolotti E, Maggini R (2016). Antioxidant power, anthocyanin content and organoleptic performance of edible flowers. Scientia Horticulturae 199:170-177.

Bor JY, Chen HY, Yen GC (2006). Evaluation of antioxidant activity and inhibitory effect on nitric oxide production of some common vegetables. Journal of Agricultural and Food Chemistry 54:1680-1686.

Cavaiuolo M, Cocetta G, Ferrante A (2013). The antioxidants changes in ornamental flowers during development and senescence. Antioxidants 2:132-155.

Chen G-L, Chen S-G, Xiao Y, Fu N-L (2018). Antioxidant capacities and total phenolic contents of 30 flowers. Industrial Crops and Products 111:430-445.

Chen G-L, Chen S-G, Xie Y-Q, Chen F, Zhao Y-Y, Luo C-X, Gao Y-Q (2015). Total phenolic, flavonoid and antioxidant activity of 23 edible flowers subjected to in vitro digestion. Journal of Functional Foods 17:243-259.

Chen N-H, Wei S (2017). Factors influencing consumers' attitudes towards the consumption of edible flowers. Food Quality and Preference 56:93100.

Chew KK, Khoo MZ, Ng SY, Thoo YY, Wan Aida WM, Ho CW (2011). Effect of ethanol concentration, extraction time and extraction temperature on the recovery of phenolic compounds and antioxidant capacity of Orthosiphon stamineus extracts. International Food Research Journal 18(4):1427-1435.

Cunningham E (2015). What nutritional contribution do edible flowers make? Journal of the Academy of Nutrition and Dietetics 115(5):856.

Deepika SD, Lakshmi SG, Sowmya LK, Sulakshana M (2014). Edible flowers - A review article. International Journal of Advanced Research in Scienceand Technology 3(1):51-57.

Dhiman MR, Kumar S, Parkash C, Kumar R, Moudgil S, Sharma S (2017). Determination of phytochemical and antioxidant activities in edible flowers. International Journal of Horticulture 7(4):26-32.

Fernandes L, Casal S, Pereira JA, Saraiva JA, Ramalhosa E (2017). Edible flowers: A review of the nutritional, antioxidant, antimicrobial properties and effects on human health. Journal of Food Composition and Analysis 60:38-50.

Filipiak K, Wilkos S (1995). Statistical calculations. Description of system AWAR IUNG Pulawy R324:1-52.

Garzón GA, Wrolstad RE (2009). Major anthocyanins and antioxidant activity of Nasturtium flowers (Tropaeolum majus). Food Chemistry 114:4449.
GhoshD (2013). A feast of flowers. Resonance 11:1004-1014.

Grzeszczuk M, Stefaniak A, Pachlowska A (2016). Biological value of various edible flower species. Acta Scientiarum Polonorum Hortorum Cultus 15(2):109-119.

Grzeszczuk M, Wesołowska A, Jadczak D, Jakubowska B (2011). Nutritional value of chive edible flowers. Acta Scientiarum Polonorum Hortorum Cultus 10(2): 85-94.

Grzeszczuk M, Stefaniak A, Meller E, Wysocka G (2018). Mineral composition of some edible flowers. Journal of Elementology 23(1): 151-162.

Huang W, Mao S, Zhang L, Lu B, Zheng L, Zhou F, ZhaoY, Li M (2017). Phenolic compounds, antioxidant potential and antiproliferative potential of 10 common edible flowers from China assessed using a simulated in vitro digestion-dialysis process combined with cellular assays. Journal of the Science of Food and Agriculture 97(14):4760-4769.

Husti A, Cantor M, Buta E, Horț D (2013). Current trends of using ornamental plants in culinary arts. ProEnvironment 6:52-58.

ISO 750 (1998). Fruit and vegetable products - Determination of titratable acidity.

Kaack K, Christensen LP, Hughes M, Eder R (2005). The relationship between sensory quality and volatile compounds in raw juice processed from elderberries (Sambucus nigra L.). European Food Research and Technology 221(3-4):244-254.

Kaisoon O, Konczak I, Siriamornpun S (2012). Potential health enhancing properties of edible flowers from Thailand. Food Research International 46:56-571.

Kelley KM, Behe BK, Biernbaum JA, Poff KL (2001). Consumer preference for edible flower color, container size, and price. HortScience 36(4):801-804.

Klepacka M (1996). Analiza żywności [Food analysis]. Fundacja Rozwój SGGW, Warszawa.

Kucekova Z, Mlcek J, Humpolicek P, Rop O, Valasek P, Saha P (2011). Phenolic compounds from Allium schoenoprasum, Tragopogon pratensis and Rumex acetos $a$ and their antiproliferative effects. Molecules 16:92079217.

Kumaran A, Karunakaran RJ (2007). In vitro antioxidant activities of methanol extracts of five Phyllanthus species from India. LWT - Food Science and Technology 40:344352.

Lee J, Durst RW, Wrolstad RE (2005). Determination of total monomeric anthocyanin pigment content of fruit juices, beverages, natural colorants, and wines by the $\mathrm{pH}$ differential method: Collaborative study. Journal of AOACInternational 88(5):1269-1278.

Li A-N, Li S, Li H-B, Xu D-P, Xu X-R, Chen F (2014). Total phenolic contents and antioxidant capacities of 51 edible and wild flowers. Journal of Functional Foods 6:319-330.

Lichtenthaler HK, Wellburn AR (1983). Determination of total carotenoids and chlorophylls a and b of leaf extracts in different solvents. Biochemical Society Transactions 603:591-592.

Loizzo MR, Pugliese A, Bonesi M, Tenuta MC, MenichiniF, XiaoJ, Tundis R (2016). Edible flowers: A rich source of phytochemicals with antioxidant and hypogycaemic activity. Journal of Agricultural and Food Chemistry 64:2467-2474. 
134

Lu B, Li M, Yin R (2015). Phytochemical content, health benefits, and toxicology of common edible flowers: A review (2000-2015). Critical Reviews in Food Science and Nutrition 56(Suppl 1):130-148.

Martín J, Navas MJ, Jiménez-Moreno AM, Asuero AG (2017). Anthocyanin pigments: Importance, sample preparation and extraction. In: Soto-Hernandez M, Palma-Tenango M, Garcia-Mateos MR(Eds). Phenolic compounds - Natural sources, importance and applications. InTech pp 117-152.

Mlček J, Rop O (2011). Fresh edible flowers of ornamental plants - a new source of nutraceutical foods. Trends in Food Science and Technology 22:561-569.

Moravčíková D, Kuceková Z, Mlček J, Rop O, Humpolícek P (2012). Compositions of polyphenols in wild chive, meadow salsify, garden sorrel and agyoncha and their anti-proliferative effect. Acta Universitatis Agriculturae et Silviculturae Mendelianae Brunensis 60(3):125-132.

Navarro-González I, González-Barrio R, García-Valverde V, Bautista-Ortín $A B$, Periago MJ (2015). Nutritional composition and antioxidant capacity in edible flowers: Characterisation of phenolic compounds by HPLC-DAD-ESI/MSn. International Journal of Molecular Sciences 16:805-822.

Newerli-Guz J (2016). The cultivation of herbal plants in Poland. Roczniki Naukowe Stowarzyszenia Ekonomistów Rolnictwa i Agrobiznesu 18(3):268-274.

Ngoitaku C, Kwannate P, Riangwong K (2016). Total phenolic content and antioxidant activities of edible flower tea products from Thailand. International Food Research Journal 23(5):2286-2290.

Petrova I, Petkova N, Ivanov I (2016). Five edible flowers - valuable source of antioxidants in human nutrition. International Journal of Pharmaceutical and Phytopharmacological Research 8(4):604-610.

Pires TCSP, Dias MI, Barros L, Calhelha RC, Alves MJ, Oliveira MBPP, Santos-Buelga C, Ferreira ICFR (2018). Edible flowers as sources of phenolic compounds with bioactive potential. Food Research International 105:580-588.

Pires TCSP, Dias MI, Barros L, Ferreira ICFR (2017). Nutritional and chemical characterization of edible petals and corresponding infusions: Valorization as new food ingredients. Food Chemistry 220:337-343.
Re R, Pellegrini N, Proteggente A, Pannala A, Yang M, Rice-Evans C (1999). Antioxidant activity applying an improved ABTS radical cation decolorization assay. Free Radical Biology and Medicine 26(9/10):12311237.

Rodrigues H, Cielo DP, Goméz-Corona C, Silveira AAS, Marchesan TA, Galmarini MV, Richards NSPS (2017). Eating flowers? Exploring attitudes and consumers' representation of edibleflowers. Food Research International 100:227-234.

Rop O, Mlcek J, Jurikova T, Neugebauerova J, Vabkova J (2012). Edible flowers - a new promising source of mineral elements in human nutrition. Molecules 17:6672-6683.

Seroczyńska A, Korzeniewska A, Sztangret-Wiśniewska J, NiemirowiczSzczytt K, Gajewski M (2006). Relationship between carotenoids content and flower or fruit flesh colour of winter squash (Cucurbita maxima Duch.). FoliaHorticulturae 18(1):51-61.

Skrajda MN (2017). Phenolic compounds and antioxidant activity of edible flowers. Journal of Education, Health and Sport 7(8):946-956.

Stefaniak A, Grzeszczuk M (2015). Charakterystyka wybranych gatunków roślin ozdobnych o kwiatach jadalnych [Characterisation of some ornamental plant species with edible flowers]. Annales UMCS, Sectio EEE, Horticultura 25(4):63-73.

Wang F, Miao M, Xia H, Yang L, Wang S, Sun G (2017). Antioxidant activities of aqueous extracts from 12 Chinese edible flowers in vitro and in vivo. Food and Nutrition Research 61(1):1-9.

Wojdyło A, Oszmiański J, Czemerys R (2007). Antioxidant activity and phenolic compounds in 32 selected herbs. Food Chemistry 105:940949.

Xiong L, Yang J, Jiang Y, Lu B, Hu Y, Zhou F, Mao S, Shen C (2014). Phenolic compounds and antioxidant capacities of 10 common edible flowers from China.Journal of Food Science 79(4):517-525.

Zhang Y-J, Gan R-Y, Li S, Zhou Y, Li A-N, Xu D-P, Li H-B (2015). Antioxidant phytochemicals for the prevention and treatment of chronic diseases. Molecules 20:21138-21156. 